\title{
Comparative Advantage of Using Biofertilizers in Indian Agroecosystems: An Analysis from the Perspectives of Stakeholders
}

\author{
Hasrat Arjjumend, Konstantia Koutouki, and Simon Neufeld
}

\section{ABSTRACT}

The use of excessive chemical fertilizers and pesticides have decreased soil microbial life and upset the balance between soil microbes and plants, negatively impacting plant nutrition, production and soil health. Biofertilizers hold the potential to revive soil biology and increase farmers' current agricultural productivity, while at the same time contributing to the soil's ability to produce more in the future. This article is part of a larger Université de Montréal study conducted with the support of Mitacs and Earth Alive Clean Technologies. The responses of farmers using and not using biofertilizers, manufacturers or suppliers of biofertilizers, and research and development scientists are captured to build cases of how microbial products (biologicals) prove to be advantageous when applied in field crops. The agronomic advantage of biofertilizers compared to conventional chemical fertilizers is well proved biologically and in economic terms. The farmers interviewed stated their preference of biofertilizers over chemical fertilizers. However, production and distribution of biofertilizers are inadequate compared to the demand for them. Studies need to be pursued to understand reasons for the supply gaps and the slow growth of biofertilizers in the agriculture sector of India and methods of linking them to farmers' preferences in order to advance protections of soil and plants in India.

Keywords: Advantage, Biofertilizers, Farmers' Preference, Fertilizers, Soil Biology.

\section{INTRODUCTION}

The widespread use of chemical fertilizers and pesticides has affected humans and their environment, and yet insect pests still remain one of the major limiting factors in sustaining the productivity of various crops [9]. Traditionally, soil biology was considered the most vital component of food production systems. Neufeld [6] stresses that 'good' soil biology is crucial for agricultural production. Good soil biology builds organic matter in the soil to store carbon and breaks organic matter down to release carbon back into the atmosphere [15]. In the quest of maximizing crop yields, excessive use of inorganic nutrients and chemical pest control products has impaired biological processes and ecological pathways in soils [3]. The use of excessive chemical fertilizers and pesticides have decreased soil microbial life and destroyed the balance between soil microbes and plants, negatively impacting plant nutrition, production, and soil health [2].

Shiva [11] establishes that contemporary societies across the world stand on the verge of collapse as soils are eroded, degraded, poisoned, buried under concrete, and deprived of life. Industrial agriculture based on a mechanistic paradigm

\footnotetext{
${ }^{1}$ An incredible diversity of organisms makes up the soil food web. They range in size from the tiniest one-celled bacteria, algae, fungi, and protozoa, to the more complex nematodes and micro-arthropods, to the visible
}

Submitted : February 8, 2021

Published : March 11, 2021

ISSN: $2684-1827$

DOI: $10.24018 /$ ejfood.2021.3.2.243

Hasrat Arjjumend*

Faculté de droit, Université de Montréal, Canada.

(e-mail: harjjumend@gmail.com,

hasrat.arjjumend@ umontreal.ca)

Konstantia Koutouki

Faculté de droit, Université de

Montréal, Canada.

(e-mail:

konstantia.koutouki@umontreal.ca) Simon Neufeld

Earth Alive Clean Technologies Inc., Canada.

(email: neufeld@earthalivect.com)

*Corresponding Author and use of fossil fuels has created ignorance and blindness to the living processes that create a living soil. Instead of focusing on the Soil Food Web ${ }^{1}$, industrial agriculture has been focused on external inputs of chemical fertilizers what Sir Albert Howard called the NPK (nitrogen, phosphorus, potassium) mentality. Biology and life have been replaced with synthetic chemistry [11].

Microbial biofertilizers have been developed as a way to recover the soil biology and sustainability of agroecosystems. Biofertilizers hold the potential to revive soil biology and increase farmers' current agricultural productivity, while at the same time contributing to the soil's ability to produce more in the future [3]. Biofertilizers are substances containing beneficial living microorganisms which, when applied to seed, plant surfaces, or soil, colonize the rhizosphere or the interior of the plant and promote growth by increasing the supply or availability of primary nutrients to the host plant [12], [14]. In the soil or rhizosphere, biofertilizers mobilize plant nutrients through their activities or make them available to the plants [8]. The benefits of biofertilizers have been cited as cost-effective, supplying up to $25-30 \%$ of the chemical fertilizer equivalent of nitrogen, providing plant-available phosphorous and potassium, increasing water absorption and 
keeping soil biologically active. Mosttafiz, Rahman and Rahman [16] claim that the broad application of microbes in sustainable agriculture is due to the genetic dependency of plants on the beneficial functions provided by symbiotic cohabitants [7]. The agronomic potential of plant-microbial symbioses proceed from the analysis of their ecological impacts, which have been best studied for N-fixing [4].

The global biofertilizers market is segmented by microorganisms into rhizobium, azotobacter, azospirillum, blue-green algae, phosphate solubilizing bacteria, mycorrhiza, and other microorganisms; by technology type into carrier enriched biofertilizers, liquid biofertilizers, and other technology types; by application into seed treatment and soil treatment; and by crop type into cereals, legumes, fruits and vegetables, plantations, and other crop types. In India, it is projected that the potential demand of biofertilizers is quite large, calculated to be 348,000 tons [13], which far exceeds the present production levels. So far, 64 biofertilizer production units have been established with the support of the Government of India [5]. These biofertilizer production units had total production of 95,000 tons of biofertilizers during 2015-16 [10]. The existing poor status of biofertilizer production and distribution, which is largely governmentsponsored, indicates that the country has huge gaps between demand and supply.

As part of a larger study conducted between September 2017 and February 2020 by the authors at Faculté de droit, Université de Montréal, with the support of Mitacs and Earth Alive Clean Technologies, the present paper focuses on advantages of using biofertilizers vis-à-vis chemical fertilizers. Four different groups of respondents were surveyed between April 2018 and March 2019 using methods of semi-structured interviews, structured interviews, informal discussions, and observation. The responses of farmers using and not using biofertilizers, manufacturers or suppliers of biofertilizers, and scientists were captured to build cases of how microbial biofertilizers (biologicals), used alone or in combination, prove to be advantageous when applied in field crops. The agronomic advantage of biofertilizers compared to conventional chemical fertilizers is well proved biologically and in economic terms. The farmers have shown their preference for biofertilizers over chemical fertilizers and have expressed higher willingness to adopt biofertilizers to revive their soil biology and soil health along with better crop yields.

\section{MethodOLOGY}

This research was conducted in India to understand the comparative advantage of using biofertilizers. Together with primary survey data obtained by interviewing respondent groups and observing field conditions, some pertinent literature was also considered for review.

\section{A. Sampling and Sample Techniques}

The following respondent groups were chosen for inclusion in the study: G.1 - Research and Development (R\&D) Scientists; G.2 - Manufacturers and Suppliers; and G.3 - Biofertilizer-Using Farmers (User Famers) \& NonUsing Farmers (Non-User Farmers). It is important to mention here the logic behind selecting the above respondent groups. Group 1 includes respondents involved in the research and development of biofertilizer products, or the scientists conducting research on microbial agents. These scientists were important because of their deep understanding of the microbiology, biotechnology, and agrochemistry of microbial biofertilizers. Group 2 respondents include those involved in the manufacturing, trade and supply chain of agro-biologicals. Perspectives of such a group of respondents were essential as they are the determinant stakeholders in the supply chain of biofertilizers. Group 3 respondents are the farmers/cultivators/growers using or not using biofertilizers. They are the direct stakeholders of the use and application of biofertilizers in the soil/crops. As this study was originally conducted in two countries - India and Ukraine - and sample size of all respondents together needed to be limited due to logistic issues, a limited number of respondents was covered in each group of respondents. Originally, the idea was not to split the respondents over different states of India; but, later, viewing the diversity of farming systems in varying agroclimatic zones of North Indian states the total sampling size of farmers/growers (Group 3 respondents) was divided into four states, although the sample size was not increased due to logistic issues and restricted funding. Further, number of sampled farmers/growers not using biofertilizers was kept lowest because they were considered representing 'control' situations; on the contrary, farmers/growers using biofertilizers were treated as reflecting the desired implications of biofertilizers when used in agroecosystems.

Table 1 characterizes the respondents in each group, including the sample size of each group, the Indian states in which these respondents were located, and the sampling and research methods employed. Table 2 presents the distribution of surveyed farmers geographically and with respect to their use of biofertilizers. All respondents except farmers/cultivators/growers falling in Group 3 were first contacted through telephone and/or email in order to make an appointment. Following the pre-appointments, the participants were physically visited and interviewed or interacted with.

For the data augmentation from each respondent group, a sampling technique was envisaged, which is identified in Table 1. Group 1 respondents were sampled using expert and snowball techniques of sampling. The manufacturers/suppliers of biologicals (Group 2 respondents) were sampled using purposive sampling and snowball sampling techniques. Lastly, the Group 3 respondents were sampled in each Indian state using stratified random sampling. All the farmers were divided into two major distinct categories: non-users of biologicals, and users of biologicals. After this basic stratification, they were randomly sampled. The composition of sampling of these farmers is illustrated in Table 2.

TABLE 1: SAMPLING DETAILS

\begin{tabular}{|c|c|c|c|c|}
\hline $\begin{array}{l}\text { Respondent } \\
\text { Group }\end{array}$ & $\begin{array}{l}\text { Sample } \\
\text { Size }\end{array}$ & Locations (States) & $\begin{array}{c}\text { Sampling } \\
\text { Method }\end{array}$ & Research Method \\
\hline $\begin{array}{l}\text { G.1 R\&D } \\
\text { Scientists }\end{array}$ & 12 & $\begin{array}{c}\text { Uttarakhand, West } \\
\text { Bengal, Telangana, } \\
\text { Punjab, Delhi }\end{array}$ & $\begin{array}{l}\text { Expert, } \\
\text { Snowball }\end{array}$ & $\begin{array}{c}\text { Informal discussion. } \\
\text { Semi-structured } \\
\text { interview }\end{array}$ \\
\hline $\begin{array}{l}\text { G.2 } \\
\text { Manufacturers } \\
\text { and Suppliers }\end{array}$ & 8 & $\begin{array}{c}\text { West Bengal, } \\
\text { Punjab, Haryana }\end{array}$ & $\begin{array}{l}\text { Snowball, } \\
\text { Purposive }\end{array}$ & $\begin{array}{c}\text { Semi-structured } \\
\text { interview; Structurec } \\
\text { interview }\end{array}$ \\
\hline $\begin{array}{c}\text { G.3 User \& } \\
\text { Non-User } \\
\text { Farmers }\end{array}$ & 36 & $\begin{array}{c}\text { Uttarakhand, Punjab, } \\
\text { Himachal Pradesh, } \\
\text { Uttar Pradesh }\end{array}$ & $\begin{array}{c}\text { Stratified } \\
\text { random }\end{array}$ & $\begin{array}{c}\text { Semi-structured } \\
\text { interview; Structurec } \\
\text { interview; } \\
\text { Observation }\end{array}$ \\
\hline
\end{tabular}


TABLE 2: COMPOSITION OF GROUP 3 RESPONDENTS

\begin{tabular}{cccccc}
\hline $\begin{array}{c}\text { Category of } \\
\text { Farmers }\end{array}$ & Punjab & $\begin{array}{c}\text { Uttar } \\
\text { Pradesh }\end{array}$ & Uttarakhand & $\begin{array}{c}\text { Himachal } \\
\text { Pradesh }\end{array}$ & Total \\
\hline $\begin{array}{c}\text { Non-Users of } \\
\text { Biologicals }\end{array}$ & 3 & 3 & 3 & 3 & 12 \\
Users of & 6 & 6 & 6 & 6 & 24 \\
$\begin{array}{c}\text { Biologicals } \\
\text { Total }\end{array}$ & 9 & 9 & 9 & 9 & 36 \\
\hline
\end{tabular}

\section{B. Methods of Data Collection}

As shown in Table 1, different data collection methods were used to augment data from the respondent groups. For instance, information from Group 1 respondents was augmented by using informal discussions and semi-structured interviews (Table 1) through applying the questions listed in Appendix 1. On the other hand, manufacturers/suppliers gave their responses in accordance with the questions listed in Appendix 2. The data-gathering methods used were semi-structured and structured interviews (Table 1). The farmers were surveyed by employing structured interviews, semi-structured interviews and observation methods (Table 1). The questions for nonusers of biologicals are listed in Table 3, and the questions for users of biologicals are listed in Table 4 .

\section{Certificat D'approbation Éthique (Ethical Approval Certificate) and its Compliance}

The Multi-Faculty Committee on Research Ethics (Comité plurifacultaire d'éthique de la recherche - CPER) of Université de Montréal issued an Ethical Approval Certificate (no. CPER-17-114-P) to the study project. During the field data collection from all respondent groups, the conditions of the Ethics Certificate were fulfilled and complied with. In compliance with the Ethical Certificate, the Consent Form was presented to each of the individual respondents in either English or Hindi. Depending on participant preference, the appropriate Consent Form was used and signed by both the respondent and field researcher. Before conducting interviews or discussions with the respondents/participants, each individual was told the objectives of the research through an Information Sheet containing statements regarding expectations from the respondent, the benefits of sharing information, confidentiality details, and the participant's right to withdraw. After adequate explanations about the research and freely-given consent of the respondent/participant, the desired information was collected from the respondent/participant.

\section{RESULTS}

A sampling of 12 farmers (3 farmers in each of 4 states) not using biofertilizers was made in India and their responses were recorded according to several parameters (Table 3). The questions were chiefly regarding the disadvantages of using chemical fertilizers and the impacts respondents observed of their use on their agroecosystems, human health and the health of domestic animals. Likewise, 24 farmers using biological inputs (3 farmers using biofertilizers, 3 using biopesticides and the remainder using both) in India were interviewed and their answers were recorded in Table 4. Most of the questions are analyzed and compared hereunder in accordance with various parameters.

\section{Soil performance under chemical fertilizers}

The majority of non-users of biologicals in all four states of India affirmed that chemical fertilizers affect the soil, plants, ecosystem and human health. The farmers of Himachal Pradesh, Punjab and Uttar Pradesh indicate that chemical fertilizers are harmful, but not as harmful as pesticides. What effects do farmers observe from using the chemical fertilizers? According to the farmers surveyed, when using chemical fertilizers, the soil becomes drought-prone, hard, compact, water-scarce, infertile, polluted and less productive. These respondents also highlighted that earthworms in the soil die and water retention capacity of the soil also decreases after using the mineral fertilizers (Table 3).

\section{Health and ecological risks from chemical fertilizers}

Most of the farmers surveyed not using biofertilizers gave their experiential opinion about the common health effects of chemical fertilizers, especially on children and women (Table 3 ). These respondents named certain common diseases that can be attributed to usage of chemical fertilizers, such as: skin diseases, kidney problems, respiratory diseases, indigestion, memory loss, lung ailments, mental and physical weakness, menstrual disorders, loss of immunity, loss of work efficiency, and eyesight weakness (Table 3, section 3). Some farmers of the Uttarakhand mountains gave a differing response by indicating "no serious health consequences observed in hilly areas" (Table 3 ). This kind of response may be correlated with the fact that mountain agroecosystems are relatively newer and use of chemicals has not reached the threshold at which farmers observe the impacts of chemicals on plants, soil, and human health. However, in other mountains areas, health impacts from chemical fertilizers are reported. Respondent farmers in these areas explained their observations of the ecological effects of chemical fertilizers (Table 3). Scientists and farmer respondents stated that water, air and soil are polluted and poisoned, along with heavy eutrophication of the water bodies. Like the users of chemical fertilizers, the users of biofertilizers also commented on the common health effects of chemical fertilizers (Table 4). These respondents expressed their perspectives that, as a consequence of using chemical fertilizers in agriculture, some illnesses occur including skin diseases, vision problems, lung disease, bone weakness, eyesight weakness, kidney problems, general weakness, kidney stones, allergies, loss of immunity and loss of memory (Table 4).

The respondent farmers compared chemical fertilizers and biofertilizers (Table 4) and reported finding that biofertilizers are safer compared to chemical fertilizers (Table 4). Regarding the comparative ecological advantage of biofertilizers, the respondent farmers using biofertilizers stated that biofertilizers, unlike chemical fertilizers, do not pollute water and air and keep the environment clean. Whereas the chemicals are not absorbed $100 \%$ by plants and leave residues which damage ecosystems, the biofertilizers are ecologically safer and do not pose public health risks (Table 4).

\section{Soil performance under biofertilizers}

Users of biofertilizers were questioned about how biofertilizers benefit the soil, plants, ecosystem, and human health. Most of the respondent farmers suggested one benefit or another (Table 4). The respondent farmers, scientists and manufacturers/suppliers said that biofertilizers increase the 
moisture increases growth and production. Biofertilizers were also confirmed to improve the soil texture and profile, while enhancing soil fertility (Table 4). Another significant advantage of using biofertilizers (alone or in combination of chemical fertilizers) indicated by respondent scientists is that they are toxin-free, non-poisonous, harmless to soil, environmentally friendly, and disease-resistant. The biofertilizers are also claimed to support plant and human health, reduce the carbon footprint associated with farming activities, and help plants grow better and more safely (Table 4).

TABLE 3: RESPONSES OF CONTROL FARMERS/GROWERS (NON-USERS OF BIOFERTILIZERS) \begin{tabular}{l} 
Questions \\
\hline 1. Soil performance under \\
chemicals \\
1.1. Do you think that chemical \\
fertilizers affect the soil, plants
\end{tabular} ecosystem and human health? 1.2. How is the soil affected after application of chemical fertilizers?

\section{Investment \& economic risks}

2.1. How much do/did you spend on buying chemical fertilizers and pesticides? (per annum per acre)

2.2. Can you calculate the economic or investment risks of crop cultivation under chemicals if the crop fails due to nutrient deficits, disease, pests (nematodes, insects, etc.)?

\section{Health and ecological risks} 3.1. What are the common health effects of chemical fertilizers? Especially on children and women.

3.2. Can you explain the ecological effects of chemical fertilizers?

\section{Other qualitative}

information

4.1. What is your preferred fertilizer?

\subsection{Do you want to use} biofertilizers?

4.3. What drives you to use biofertilizers in the future?

4.4. Which company/brand biofertilizer(s) do you like to use?

\section{Additional Questions} 5.1. Do you prefer locally made products or foreign products?

5.2. Would you be willing to pay more for a foreign product than for a local product?

5.3. Scale 1-10: How willing are you to try a new/innovative product?

5.4. Which (local or international) organic certification do you trust?
- It is harmful, but not seriously harmful

- Yes

- Soil became droughtprone

- Soil gets hard and drought-prone

- Fertility of soil deteriorates

- INR 11000

- INR 3500

- INR 25000

- Total loss

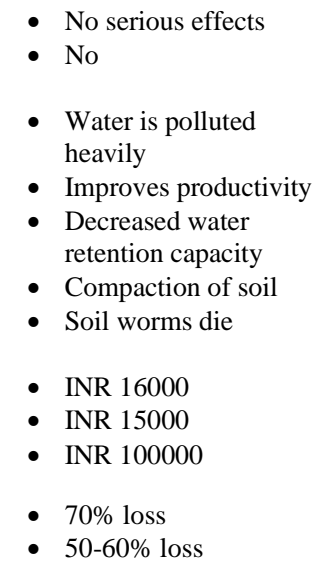

No serious health impact

- Skin, kidney, respiratory diseases

- Weakness, indigestion memory loss

- Water, air and soil are poisoned

- No serious health consequences observed in hilly areas

- Not known

- Kidney and lung ailments

- Eutrophication

- NPK, Urea
- Mix NPK
- Urea, DAP
(diammonium
phosphate)
- No
- Yes
- Chemical fertilizers are
- expensive
- Health protection

- Tata Chemicals, Bayer
- Yes

- Soil faces drought conditions and requires more irrigation

- Worms in the soil have died

- INR 20000

- INR 6000

- Loss of INR 200000250000 per annum per hectare

- Loss of INR 125000 per annum per hectare

- Paddy loss of INR 200000-250000 per annum per hectare

- Wheat loss of INR 150000 per annum per hectare

- Mental and physical weakness

- Skin related problems

- Menstrual disorders

- Loss of immunity

- Loss of work efficiency

- Water, air, soil are polluted Uttar Pradesh

Yes

- Soil getting hard

- Soil losing productivity

- Loss of moisture

- Proneness to drought

- Loss of fertility

- INR 1000

- INR 7000

- INR 30000

- $50 \%$ loss
- DAP

- MOP (muriate of potash or potassium chloride)

- Urea

- SSP (single super phosphate)

- Yes

- Biofertilizer is cheaper

- Biofertilizers are safe and green

- Safe for human health, livestock and soil

- Tata Chemicals
- Eyesight weakness

- General weakness

- Skin disorders

- Immunity loss

- Water and soil are polluted

- Eutrophication

\section{- Urea, NPK}

- DAP

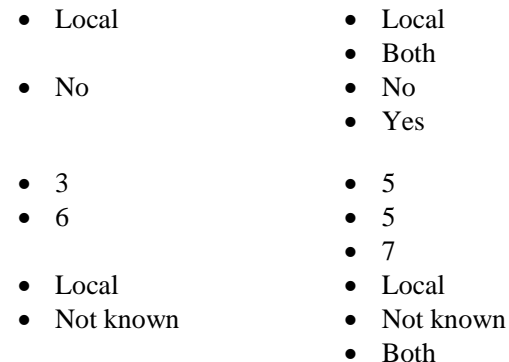

- Both

- Local

- Yes

- 7

- 8

- Local

- Not known
- No adverse effect on human health and soil

- Biofertilizers are economic 


\begin{tabular}{|c|c|c|c|c|c|}
\hline & Questions & Himachal Pradesh & Uttarakhand & Punjab & Uttar Pradesh \\
\hline \multicolumn{6}{|c|}{$\begin{array}{l}\text { 1. Soil performance under } \\
\text { biologicals }\end{array}$} \\
\hline 1.1 & $\begin{array}{l}\text { Do you think that } \\
\text { biofertilizers benefit the } \\
\text { soil, plants, ecosystem } \\
\text { and human health? In } \\
\text { what way? }\end{array}$ & $\begin{array}{l}\text { Moisture remains for long } \\
\text { period and moisture } \\
\text { increases growth and } \\
\text { production } \\
\text { - Biofertilizer is toxin-free } \\
\text { - Yes } \\
\text { - Less disease and more } \\
\text { production } \\
\text { - Plants grow better and safe } \\
\text { for human health }\end{array}$ & $\begin{array}{l}\text { - } \text { Yes } \\
\text { - Biofertilizers increase } \\
\text { water holding } \\
\text { capacity } \\
\text { - It benefits the soil }\end{array}$ & $\begin{array}{l}\text { - Soil is improved } \\
\text { - It is harmless to soil } \\
\text { - It reduces carbon footprint } \\
\text { - Beneficial for soil } \\
\text { - Good for plant and human } \\
\text { - health } \\
\text { - } \text { - Plants and human health } \\
\text { - It is non-poisonous } \\
\text { - Environment friendly }\end{array}$ & - Yes \\
\hline 1.2 & $\begin{array}{l}\text { Can you describe the } \\
\text { changed attributes of the } \\
\text { soil once biofertilizers } \\
\text { are used? }\end{array}$ & $\begin{array}{l}\text { - Soil retains moisture in } \\
\text { which nutrients dissolve } \\
\text { and become available to } \\
\text { plants. Moisture remains } \\
\text { in dry spells too. } \\
\text { - Productivity of soil is } \\
\text { increased } \\
\text { - It makes nutrients and } \\
\text { micro-elements available } \\
\text { to plants } \\
\text { - It mobilizes nutrients and } \\
\text { increases resistance in } \\
\text { plants }\end{array}$ & $\begin{array}{l}\text { - Microbes fix the } \\
\text { nitrogen and keep } \\
\text { agroecosystem clean } \\
\text { - Moisture remains } \\
\text { longer in soil } \\
\text { - Not harmful to } \\
\text { ecology } \\
\text { - It increases soil } \\
\text { fertility and plant } \\
\text { growth }\end{array}$ & $\begin{array}{l}\text { - Microbes of the biofertilizers } \\
\text { solubilize nutrients and } \\
\text { make available to plants. } \\
\text { - Agroecosystem is supported } \\
\text { - Worms survive better to } \\
\text { support the soil } \\
\text { - Beneficial for human } \\
\text { - } \text { - Soil fertility increases } \\
\text { - Better soil health } \\
\text { - Microbes fix the nutrients } \\
\text { for plants }\end{array}$ & $\begin{array}{l}\text { - Enemy insects } \\
\text { and pests are } \\
\text { defied } \\
\text { - Microbes are } \\
\text { beneficial }\end{array}$ \\
\hline 1.3 & $\begin{array}{l}\text { Has the soil become } \\
\text { softer after application } \\
\text { of biofertilizers? If yes, } \\
\text { can you explain the } \\
\text { reasons behind this? }\end{array}$ & $\begin{array}{l}\text { - Yes } \\
\text { - Soil is not poisoned } \\
\text { - Plant roots go deeper } \\
\text { easily } \\
\text { - Microbes make good } \\
\text { colonies } \\
\text { - Soil particles become non- } \\
\text { crystals, which help soil } \\
\text { hold water and air. }\end{array}$ & $\begin{array}{ll}\text { - } & \text { Yes } \\
\text { - } & \text { Microbes work in soil } \\
\text { - Soil gets soft and } \\
\text { supportive to plants } \\
\text { - } \text { Microbes soften the } \\
\text { soil and increases } \\
\text { moisture }\end{array}$ & $\begin{array}{l}\text { - Soil gets softer by the } \\
\text { microbes } \\
\text { - Soil becomes drought } \\
\text { resistant } \\
\text { - Soil gets moist } \\
\text { - No soil contamination }\end{array}$ & \\
\hline \multicolumn{6}{|c|}{$\begin{array}{l}\text { 2. Soil-water regime under } \\
\text { biologicals (especially } \\
\text { biofertilizers) }\end{array}$} \\
\hline 2.1 & $\begin{array}{l}\text { How many irrigation } \\
\text { periods were required } \\
\text { for a crop (e.g. wheat) } \\
\text { grown without } \\
\text { biofertilizer(s) usage? } \\
\text { Crop-wise data }\end{array}$ & $\begin{array}{l}\text { - Rainfed agriculture } \\
\text { - It depends on rain } \\
\text { - } 7-8 \text { times }\end{array}$ & $\begin{array}{l}\text { - It depends on rainfall } \\
\text { - } \text { Rainfed agriculture } \\
\text { - } 9-10 \text { times }\end{array}$ & $\begin{array}{l}\text { - Frequent irrigation required } \\
\text { - 6-8 irrigations }\end{array}$ & $\begin{array}{ll}\text { - } & 7-10 \text { irrigations } \\
\text { - } & 6-9 \text { irrigations } \\
\text { - } & 8-10 \text { irrigations } \\
\text { - } & 7-10 \text { irrigations } \\
\text { - } & 6-9 \text { irrigations } \\
\text { - } & 8-10 \text { times }\end{array}$ \\
\hline 2.2 & $\begin{array}{l}\text { How many irrigations } \\
\text { are required for a crop } \\
\text { (e.g. wheat) grown with } \\
\text { biofertilizer(s) usage? } \\
\text { Crop-wise data }\end{array}$ & - Less irrigation is required & - 5-6 times & $\begin{array}{l}\text { - Less irrigation required } \\
\text { - 4-5 irrigations }\end{array}$ & $\begin{array}{ll}\text { - } & 6-9 \text { irrigations } \\
\text { - } & 6-8 \text { irrigations } \\
\text { - } & 6-9 \text { irrigations } \\
\text { - } & 6-8 \text { irrigations }\end{array}$ \\
\hline 2.3 & $\begin{array}{l}\text { Can you tell about the } \\
\text { longevity of moisture in } \\
\text { the soil before and after } \\
\text { usage of biofertilizer(s)? } \\
\text { If possible, crop-wise } \\
\text { data }\end{array}$ & $\begin{array}{l}\text { - Soil retains moisture for } \\
\text { longer time in soil } \\
\text { - It depends on moisture } \\
\text { level } \\
\text { - Soil get soft }\end{array}$ & $\begin{array}{l}\text { - Moisture continues } \\
\text { for quite longer } \\
\text { - Longevity of moisture } \\
\text { increases } \\
\text { - Yes }\end{array}$ & $\begin{array}{l}\text { - Moisture increases with } \\
\text { prolonged period } \\
\text { - Moisture longevity increases } \\
\text { - Moisture remains }\end{array}$ & \\
\hline 2.4 & $\begin{array}{l}\text { How do biofertilizers } \\
\text { help the soil in summer } \\
\text { and dry season? }\end{array}$ & $\begin{array}{l}\text { - Soil becomes soft } \\
\text { - Microbial colonies create } \\
\text { a soft layer on soil }\end{array}$ & $\begin{array}{l}\text { - Soil remain moist for } \\
\text { longer } \\
\text { - Soil moisture } \\
\text { increases }\end{array}$ & $\begin{array}{l}\text { - Humus is increased } \\
\text { - Plant growth is increased } \\
\text { - Drought is mitigated }\end{array}$ & - Better results \\
\hline 2.5 & $\begin{array}{l}\text { Can you explain how } \\
\text { biofertilizers increase } \\
\text { water holding capacity } \\
\text { of soil? }\end{array}$ & $\begin{array}{l}\text { Before using biofertilizers, } \\
\text { soil had to dry quickly; but } \\
\text { after the use soil retains } \\
\text { moisture for longer }\end{array}$ & $\begin{array}{l}\text { It increases water } \\
\text { holding capacity }\end{array}$ & $\begin{array}{l}\text { - Humus increases water } \\
\text { holding capacity } \\
\text { - Soil texture changes }\end{array}$ & \\
\hline 2.6 & $\begin{array}{l}\text { Can you describe how } \\
\text { increased moisture } \\
\text { content enhances } \\
\text { nutrition intake by the } \\
\text { plant roots? }\end{array}$ & $\begin{array}{l}\text { Plant roots can absorb the } \\
\text { dissolved nutrients easily } \\
\text { from moist soil. } \\
\text { - Effect of dry spell is } \\
\text { minimized }\end{array}$ & $\begin{array}{l}\text { Moisture solubilizes } \\
\text { nutrients and } \\
\text { enhances uptake by } \\
\text { plant roots }\end{array}$ & $\begin{array}{l}\text { - Nutrients intake is facilitated } \\
\text { by moisture } \\
\text { - Resistance to droughts } \\
\text { - Nutrients intake increases }\end{array}$ & \\
\hline \multicolumn{6}{|c|}{$\begin{array}{l}\text { 3. Comparative yield } \& \\
\text { characteristics of } \\
\text { produce }\end{array}$} \\
\hline 3.1 & $\begin{array}{l}\text { How do you measure } \\
\text { the (comparative) crop } \\
\text { productivities accruing } \\
\text { after usage of } \\
\text { biofertilizer(s)? }\end{array}$ & $\begin{array}{l}\text { - Production increased } \\
\text { - Better production } \\
\text { - Soil productivity increased } \\
\text { - } 15 \% \text { increase }\end{array}$ & $\begin{array}{l}\text { - More production } \\
\text { - Increased yield }\end{array}$ & $\begin{array}{l}\text { - } \text { Yes } \\
\text { - Better production } \\
\text { - } \text { Better yields }\end{array}$ & \\
\hline
\end{tabular}


TABLE 4: CONTINUATION

\begin{tabular}{|c|c|c|c|c|c|}
\hline & Questions & Himachal Pradesh & Uttarakhand & Punjab & Uttar Pradesh \\
\hline 3.2 & $\begin{array}{l}\text { How is the farm } \\
\text { produce (grains, fruits, } \\
\text { tubers) different when } \\
\text { biofertilizer(s) used? } \\
\text { [taste, color, quantity, } \\
\text { shelf-life, etc.] }\end{array}$ & $\begin{array}{l}\text { - Tubers, grains and fruits } \\
\text { are more tasty } \\
\text { - Better fruits and grains } \\
\text { with extended shelf life } \\
\text { - Grains with better taste } \\
\text { and size } \\
\text { - Quality is far better } \\
\text { - Plants grow better }\end{array}$ & - Better produce & $\begin{array}{l}\text { Better quality of grains and } \\
\text { fruits } \\
\text { - Biofertilizer leave beneficial } \\
\text { impacts on produce } \\
\text { - Better taste of grains }\end{array}$ & $\begin{array}{l}\text { Grains, fruits, } \\
\text { tubers are better } \\
\text { in production and } \\
\text { quality }\end{array}$ \\
\hline \multicolumn{6}{|c|}{$\begin{array}{l}\text { 4. Comparative investment } \\
\text { \& economic risks }\end{array}$} \\
\hline 4.1 & $\begin{array}{l}\text { How much do/did you } \\
\text { spend on buying } \\
\text { chemical fertilizers and } \\
\text { pesticides? (per annum } \\
\text { per acre) }\end{array}$ & $\begin{array}{ll}\text { - } & \text { INR } 1500 \\
\text { - } & \text { INR } 7000 \\
\text { - INR } 40000 \\
\text { - } \\
\text { - INR } 12000 \\
\text { - } \text { INR } 15000 \\
\text { INR } 4000\end{array}$ & $\begin{array}{ll}\text { - } & \text { INR } 2500 \\
\text { - } & \text { INR } 3000 \\
\text { - } & \text { INR } 15000 \\
\text { - } & \text { INR } 15000 \\
\text { - } & \text { INR } 1000 \\
\text { - } & \text { INR } 250000\end{array}$ & $\begin{array}{l}\text { - } \text { INR } 200000 \\
\text { - } \text { INR } 6000-9000 \\
\text { - } \text { INR } 60000-85000 \\
\text { - } \text { INR } 32000-40000 \\
\text { - } \text { INR } 9000 \\
\text { INR } 100000\end{array}$ & $\begin{array}{ll}\text { - } & \text { INR } 15000 \\
\text { - } & \text { INR } 9000 \\
\text { - } & \text { INR } 80000 \\
\text { - } & \text { INR } 15000 \\
\text { - } & \text { INR } 9000 \\
\text { - } & \text { INR } 18000- \\
& 80000\end{array}$ \\
\hline 4.2 & $\begin{array}{l}\text { How much do/did you } \\
\text { spend on buying } \\
\text { biofertilizers and } \\
\text { biopesticides? (per } \\
\text { annum per acre) }\end{array}$ & 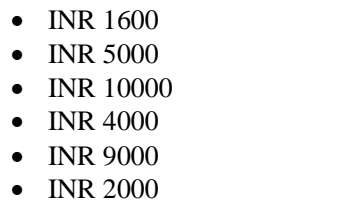 & $\begin{array}{ll}\text { - } & \text { INR } 1500 \\
\text { - } & \text { INR } 1500 \\
\text { - } & \text { INR } 5000 \\
\text { - } & \text { INR } 0 \\
\text { - } & \text { INR } 50000\end{array}$ & $\begin{array}{l}\text { - } \text { INR } 65000 \\
\text { - } \text { INR } 1000-2000 \\
\text { - } \text { INR } 5000-9000 \\
\text { - } \text { INR } 8000-10000 \\
\text { - } \text { INR } 3000 \\
\text { INR } 30000-40000\end{array}$ & $\begin{array}{l}\text { - } \text { INR } 9000 \\
\text { - } \text { INR } 6000 \\
\text { - } \text { INR } 15000 \\
\text { - } \text { INR } 9000 \\
\text { - } \text { INR } 6000 \\
\text { - } \text { INR } 9000-15000\end{array}$ \\
\hline 4.3 & $\begin{array}{l}\text { Can you calculate the } \\
\text { economic or investment } \\
\text { risks of crop cultivation } \\
\text { under chemicals if the } \\
\text { crop fails due to } \\
\text { nutrients' deficit, } \\
\text { disease, pests, } \\
\text { nematodes, insects, } \\
\text { etc.? }\end{array}$ & $\begin{array}{l}\text { - } 60 \% \text { loss } \\
\text { - } 75-90 \% \text { loss } \\
\text { - } \quad \text { INR } 250000 \text { loss }\end{array}$ & $\begin{array}{l}\text { - } 45 \% \text { loss } \\
\text { - } 60-90 \% \text { loss } \\
\text { - } 50 \% \text { loss } \\
\text { - } 60 \% \text { loss }\end{array}$ & & $\begin{array}{l}\text { - } 70 \% \text { loss } \\
\text { - } 90 \% \text { loss } \\
\text { - } 70 \% \text { loss } \\
\text { - } 80 \% \text { loss }\end{array}$ \\
\hline 4.4 & $\begin{array}{l}\text { What investment or } \\
\text { economic risks are } \\
\text { involved if the crops } \\
\text { grown by using } \\
\text { biologicals? }\end{array}$ & $\begin{array}{l}\text { - } 30 \% \text { loss } \\
\text { - } 25-40 \% \text { loss }\end{array}$ & $\begin{array}{l}\text { - Loss reduces } \\
\text { - Bearable loss } \\
\text { - Less loss }\end{array}$ & - Risk not calculated & $\begin{array}{l}\text { - } 35-40 \% \text { loss } \\
\text { - } 40 \% \text { loss }\end{array}$ \\
\hline 4.5 & $\begin{array}{l}\text { Comparison of risks } \\
\text { between both situations }\end{array}$ & $\begin{array}{l}\text { - Risks reduce considerably } \\
\text { if biologicals are used }\end{array}$ & $\begin{array}{l}\text { - Chemical farming has } \\
\text { more losses }\end{array}$ & $\begin{array}{l}\text { - Risks in chemicals are very } \\
\text { high }\end{array}$ & - $40 \%$ difference \\
\hline \multicolumn{6}{|c|}{$\begin{array}{l}\text { 5. Comparative health and } \\
\text { ecological risks }\end{array}$} \\
\hline 5.1 & $\begin{array}{l}\text { What are the common } \\
\text { health effects of } \\
\text { chemical fertilizers? } \\
\text { Examples }\end{array}$ & $\begin{array}{l}\text { - Skin diseases, vision } \\
\text { problems } \\
\text { - No serious problem } \\
\text { - Lungs disease } \\
\text { - Bone and eyesight } \\
\text { weakness } \\
\text { - Kidney problems } \\
\text { - General weakness }\end{array}$ & $\begin{array}{ll}\text { - } & \text { In long run, many } \\
& \text { health problems arise } \\
\text { - } & \text { Kidney stone } \\
\text { - } & \text { Allergy } \\
\text { - } & \text { Skin disease }\end{array}$ & $\begin{array}{l}\text { - Loss of immunity } \\
\text { - Loss of memory } \\
\text { - Skin diseases } \\
\text { - Weakness }\end{array}$ & \\
\hline 5.2 & $\begin{array}{l}\text { Do you think that } \\
\text { biofertilizers are safer } \\
\text { compared to chemical } \\
\text { fertilizers? }\end{array}$ & $\begin{array}{l}\text { - Yes } \\
\text { - Biofertilizers are safer }\end{array}$ & - Yes & - Yes & - Yes \\
\hline 5.3 & $\begin{array}{l}\text { What is comparative } \\
\text { ecological advantage of } \\
\text { biofertilizers? }\end{array}$ & $\begin{array}{l}\text { - They do not pollute water } \\
\text { and air } \\
\text { - They keep environment } \\
\text { clean } \\
\text { - Chemicals are not } \\
\text { absorbed } 100 \% \text { by plants; } \\
\text { residues damage } \\
\text { ecosystems. }\end{array}$ & $\bullet$ & - Ecologically safer & - Safe \\
\hline \multicolumn{6}{|c|}{$\begin{array}{l}\text { 6. Other qualitative } \\
\text { information about } \\
\text { farmer's preferences }\end{array}$} \\
\hline 6.1 & $\begin{array}{l}\text { What is preferred } \\
\text { fertilizer? }\end{array}$ & - Urea & $\begin{array}{l}\text { - } \text { NPK } \\
\text { - Urea } \\
\text { - } \text { Bioproduct } \\
\text { - } \text { DAP }\end{array}$ & $\begin{array}{ll}\text { - } & \text { Rhizobium } \\
\text { - NPK } \\
\text { - } \text { DAP }\end{array}$ & $\begin{array}{ll}\text { - } & \text { DAP } \\
\text { - } & \text { Urea (NPK) } \\
\text { - } & \text { Trichoderma }\end{array}$ \\
\hline 6.2 & $\begin{array}{l}\text { Is biofertilizer preferred } \\
\text { over chemical } \\
\text { fertilizer? Why? }\end{array}$ & $\begin{array}{l}\text { - Yes. It is better for human } \\
\text { health and production } \\
\text { - Yes }\end{array}$ & $\begin{array}{l}\text { - Yes } \\
\text { - Vermicompost } \\
\text { - Rhizobium } \\
\text { - Trichoderma } \\
\text { - Organic fertilizer }\end{array}$ & $\begin{array}{l}\text { - } \text { Yes } \\
\text { - } \text { Biofertilizer } \\
\text { - Safer }\end{array}$ & $\begin{array}{l}\text { - } \quad \text { Yes } \\
\text { - Safe and cheaper }\end{array}$ \\
\hline
\end{tabular}




\begin{tabular}{|c|c|c|c|c|c|}
\hline & Questions & Himachal Pradesh & Uttarakhand & Punjab & Uttar Pradesh \\
\hline 6.3 & $\begin{array}{l}\text { Are chemical fertilizers } \\
\text { and biofertilizer(s) used } \\
\text { simultaneously? }\end{array}$ & $\begin{array}{ll}\text { - } & \text { No } \\
\text { - } & \text { Yes }\end{array}$ & - Yes & - Yes & \\
\hline 6.4 & $\begin{array}{l}\text { What are perceived or } \\
\text { recorded advantages of } \\
\text { using biofertilizers? }\end{array}$ & $\begin{array}{l}\text { - Production sustainability } \\
\text { and input cost reduction } \\
\text { - Cheaper }\end{array}$ & $\begin{array}{l}\text { - Ecologically safe } \\
\text { - Organic farming }\end{array}$ & $\begin{array}{l}\text { - Environmentally safer } \\
\text { - It reduces impact of } \\
\text { chemicals }\end{array}$ & - Safer and cheaper \\
\hline 6.5 & $\begin{array}{l}\text { What drives you to } \\
\text { spend on biofertilizers? }\end{array}$ & $\begin{array}{l}\text { - Cheaper and safe } \\
\text { - Bring back the traditional } \\
\text { practices } \\
\text { - Protection of ecology from } \\
\text { chemicals }\end{array}$ & - Cheaper and safe & $\begin{array}{l}\text { - Poison free } \\
\text { - Healthy environment }\end{array}$ & $\begin{array}{l}\text { - No harm to } \\
\text { ecology }\end{array}$ \\
\hline 6.6 & $\begin{array}{l}\text { Which company/brand } \\
\text { biofertilizer(s) do you } \\
\text { use or like to use? }\end{array}$ & $\begin{array}{l}\text { - } \text { Trichoderma } \\
\text { - } \text { Pseudomonas } \\
\text { - Metarhyzime } \\
\text { - } \text { PSB, KMB }\end{array}$ & - Krishma & & \\
\hline \multicolumn{6}{|c|}{ 7. Additional Questions } \\
\hline 7.1 & $\begin{array}{l}\text { Do you prefer locally } \\
\text { made products or } \\
\text { foreign products } \\
\text { (biofertilizers or } \\
\text { biopesticides)? }\end{array}$ & $\begin{array}{l}\text { - Both } \\
\text { - Local } \\
\text { - } \text { It depends on CFU count }\end{array}$ & - Local & $\begin{array}{ll}\text { - } & \text { Both } \\
\text { - } & \text { Local }\end{array}$ & - Both \\
\hline 7.2 & $\begin{array}{l}\text { Would you be willing } \\
\text { to pay more for a } \\
\text { foreign product than for } \\
\text { a local product? }\end{array}$ & $\begin{array}{l}\text { - Yes } \\
\text { - No } \\
\text { - If found better }\end{array}$ & $\begin{array}{l}\text { - Yes } \\
\text { - No }\end{array}$ & $\begin{array}{l}\text { - } \text { Yes } \\
\text { - No }\end{array}$ & - Yes \\
\hline 7.3 & $\begin{array}{l}\text { Scale 1-10: How } \\
\text { willing are you to try a } \\
\text { new/ innovative } \\
\text { product? }\end{array}$ & $\begin{array}{l}\text { - } 8 \\
\text { - } 6 \\
\text { - } 10 \\
\text { - } 8 \\
\text { - } 9 \\
\text { - } 8\end{array}$ & $\begin{array}{l}\text { - } 4 \\
\text { - } 4 \\
\text { - } 7 \\
\text { - } 9 \\
\text { - } 7 \\
\text { - } 9\end{array}$ & $\begin{array}{l}-1 \\
\text { - } 7 \\
\text { - } 7 \\
\text { - } 6 \\
-\quad 6 \\
\text { - } 7\end{array}$ & $\begin{array}{l}\text { - } 8 \\
\text { - } 9 \\
\text { - } 9 \\
\text { - } 8 \\
\text { - } 9 \\
\text { - } 9\end{array}$ \\
\hline 7.4 & $\begin{array}{l}\text { Which (local or } \\
\text { international) organic } \\
\text { certification do you } \\
\text { trust? }\end{array}$ & $\begin{array}{l}\text { - Both } \\
\text { - International }\end{array}$ & $\begin{array}{l}\text { - Local } \\
\text { - Both }\end{array}$ & & \\
\hline 7.5 & $\begin{array}{l}\text { What soil amendment } \\
\text { products do you } \\
\text { currently use? }\end{array}$ & $\begin{array}{l}\text { - Rhizobium } \\
\text { - Vermicompost, Krishma } \\
\text { - Waste decomposer } \\
\text { - Azotobacter }\end{array}$ & $\begin{array}{l}\text { - Rhizobium } \\
\text { - Vermicompost }\end{array}$ & & \\
\hline 7.6 & $\begin{array}{l}\text { Are you experiencing } \\
\text { problems with } \\
\text { impoverished soil? }\end{array}$ & - No & $\begin{array}{l}\text { - Yes } \\
\text { - No }\end{array}$ & - No & - No \\
\hline
\end{tabular}

Farmers, scientists, and manufacturers/suppliers also described how the attributes of soil change once biofertilizers are used. They explained that biofertilizers have microorganisms that fix the nutrients, including nitrogen, available in soil for the plants. In other words, microbes in the (solubilizing) biofertilizers solubilize macro- and micronutrients in the soil and make them more available to plant roots. So, as a result of using the biofertilizers, not only are the soil fertility and productivity increased but the entire agroecosystem remains resilient, strong and clean (Table 4). Another aspect of microbes, according to respondent scientists, acting in the soil is the ability to enhance soil's water-retention capacity, enabling the soil to retain moisture in which nutrients dissolve and become available to plants. Moisture also remains longer in the soil and sustains soil during dry spells. Farmers shared their observation that soil fauna (e.g., earthworms) survive better when biofertilizers are applied in the soil (Table 4). Some biofertilizers have additional strength to defy enemy insects and pests, thereby reducing the use of plant-protection chemicals. The surveyed farmers using biofertilizers reported that the biofertilizers do not negatively affect the soil environment and ecology (Table 4). Lastly, a farmer articulated that biofertilizers increase stress/pest resistance in crop plants.
Has the soil become less compact after application of biofertilizers? The farmers affirmed that the microbes soften the soil by increasing moisture levels (Table 4). Respondent scientists expressed their perspectives that through the formation of microbe colonies on or below surface of the soil, the soil particles aggregate together, which helps soil hold water and air. As a result, plant roots can grow deeper more easily. As respondent farmers opined, soil also becomes more drought resistant with no contamination of any sort (Table 4).

\section{Soil-water regime under biofertilizers}

The farmers using biofertilizers were asked about the amount of irrigation required to grow a crop (e.g., wheat) without using biofertilizers. A few respondent farmers using biofertilizers expressed that their farming is rainfed and the irrigation of crops solely depends on the quantity of rainfall (Table 4). However, the majority of respondents gave a reference figure of frequency of irrigation ranging from 6-8 to $9-10$ irrigations. The median of all 9 observations of irrigation frequencies comes to 8.5 (Table 4). Based on this, more than 8 irrigations were needed to grow a crop (e.g., wheat) in the absence of biofertilizers. The same farmers were also asked to compare how many irrigations are required for a crop (e.g., wheat) grown with the use of biofertilizer(s). They responded that a smaller number of irrigations are typically required for a crop if biofertilizer is applied (Table 
4). Six respondents reported on the frequency of irrigation required when biofertilizers are used in soil. The median of all 6 observations of these irrigation frequencies was 6.5 (Table 4). Based on this, more than 6 irrigation were needed to grow a crop (e.g., wheat) when biofertilizers are being used by the farmers. This comparison of irrigation requirements leads us to conclude that at least 2 irrigation can be saved for a crop like wheat once biofertilizers are applied to the soil.

The next question was to understand the longevity of moisture in the soil before and after the usage of biofertilizer(s). The surveyed farmers using biofertilizers have expressed their opinions that soil retains moisture for a significantly longer time if biofertilizers are used. However, increasing the moisture retention also depends on the existing moisture level in soil (Table 4). How do biofertilizers help the soil in summer and dry season? This question was answered by farmer respondents who highlighted that soil becomes soft as the microbial colonies create a soft layer on soil (Table 4). They articulated that biofertilizers increase the humus that causes plant growth, resistance to drought and water-holding capacity of the soil (Table 4). The way in which biofertilizers increase the water-holding capacity of soil was answered by farmers in terms of changes in soil texture; they told their observation that before using biofertilizers soil dried quickly but after the use of biofertilizers soil retains moisture for longer (Table 4).

The question "can you describe how increased moisture content enhances nutrition intake by the plant roots?" was raised, and the respondent farmers reported that plant roots can absorb the dissolved nutrients easily from moist soil once the biofertilizers are used (Table 4). Moisture solubilizes nutrients and enhances uptake by plant roots and hence nutrient intake is facilitated by retained moisture. Therefore, the negative effects of a dry spell are minimized (Table 4).

\section{Comparative yield \& characteristics of produce}

During the field studies, the farmers gave their feedback about the effect of biofertilizers on a qualitative change in crop production following the use of biofertilizers. To the question "how do you measure the (comparative) crop productivities accruing after usage of biofertilizer(s)?", the farmers responded that they observed an increase in yields and production from the crops they grow (Table 4). A farmer quantified this increase in yield and production to be $15 \%$ after using biofertilizers (Table 4).

The quality of farm produce, in terms of taste, color, quantity, and shelf-life, may also change when farmers use biofertilizers. In light of this, the question "how is the farm produce (grains, fruits, tubers) different when biofertilizers are used?" was posed to the respondent farmers (Table 4). Farmers replied that the tubers, grains and fruits have better taste, size, quality, production, shelf-life, and color after the use of biofertilizers. According to them, biofertilizers produce beneficial impacts on farm produce as the plants grow better in a number of respects (Table 4).

\section{Comparative investment and economic risks}

The respondent users of chemical fertilizers were asked how much do/did they spend on buying the chemical fertilizers and pesticides (Table 3). Ten farmers estimated their expenditure, with an average of Indian rupees (INR) 13,450 per annum per acre (Table 3). From among 24 surveyed farmers in India who use biofertilizers and biopesticides, 23 farmers gave figures of their expenditure on chemical fertilizers and pesticides. Their spending on chemicals ranged from INR 1000 to INR 250,000 per annum per acre (averaging INR 43,370 per annum per acre) (Table 4). Among those using biofertilizers and biopesticides, 22 farmers responded regarding their expenditures on biofertilizers and biopesticides, with an average of INR 12,141 per annum per acre (Table 4). Compared with the average spending on chemicals, this spending of INR 12,141 per annum per acre on biofertilizers/biopesticides (Table 4) is far less than average spending of INR 13,450 per annum per acre on chemical fertilizers and pesticides by 12 chemical-using respondent farmers (Table 3) and average spending of INR 43,370 per annum per acre (Table 4) on chemical fertilizers and pesticides by 24 biofertilizer-using respondent farmers.

Farmers who do not use biofertilizers provided a rough calculation of the economic or investment risks of crop cultivation if the crop fails due to nutrient deficit, disease, pests (including nematodes, and insects) (Table 3). Several farmers assessed these risks from $50 \%$ to $70 \%$ (with an average of 60\%) of their total investment (Table 3). On the other hand, other farmers expressed these losses or risks in terms of amounts ranging from INR 125,000 to INR 250,000 per hectare per annuum (Table 3). Like users of chemical fertilizers, the users of biofertilizers and biopesticides were also asked the question, "can you calculate the economic or investment risks of crop cultivation under chemicals if the crop fails due to nutrients' deficit, disease, pests, nematodes, insects, etc.?" The farmers using biofertilizers and biopesticides have estimated the risk when growing without biofertilizers to range from $45 \%$ to $90 \%$, with the average of $68 \%$ (Table 4). A few farmers expressed this loss due to chemicals to be around INR 250,000 per annum per hectare (Table 4).

Farmers using biofertilizers were also asked, "What investment or economic risks are involved if the crops are grown by using biologicals?" This risk was assessed to be between $25 \%$ and $40 \%$, and, according to the respondents, this risk is bearable (Table 4). This value was considerably lower than reported for chemically-grown crops, indicating that risks can be reduced if biologicals are used, and that chemical farming can produce more losses (Table 4).

\section{Farmers' preferences for fertilizers and biofertilizers}

The users of chemical fertilizers were asked for their preferences of using fertilizers and their potential preferences if biofertilizers are offered to them (Table 3). Similarly, users of biofertilizers expressed their preferences (Table 4). Usage of chemicals in crops indicates that most of the nutrients are nitrogen, phosphorus and potash. Micronutrients and calcium or magnesium received the least priority. As recorded in Tables 3 and 4, common fertilizers included NPK (nitrogen, phosphorus, potassium), calcium nitrate, urea mixture, DAP (diammonium phosphate), MOP (muriate of potash or potassium chloride) and SSP (single super phosphate). The users of biofertilizers also included their choice of bioproducts such as rhizobium (Table 4).

The willingness of farmers to use biofertilizers was understood through the questions posed to them. Interestingly, some farmers in the mountain areas (Himachal Pradesh and Uttarakhand) refused to use biofertilizers. Outside of this group, the majority of farmers in all profiled states agreed to use biofertilizers (Table 3). Many of the surveyed farmers provided insights into what may drive them 
to use biofertilizers in the future. According to them, biofertilizers are more inexpensive overall compared to chemical fertilizers, and are safe, green, and protect the health of humans, livestock, and soil. They have no adverse effect on plants, human health, and soil microflora (Table 3). The biofertilizers may be used in combination of chemical fertilizers in specified ratios.

Reasons for preferring biofertilizers over the chemical fertilizers were explored with the respondent farmers using biofertilizers (Table 4). These farmers confirmed that they use chemical fertilizers and biofertilizer(s) simultaneously (Table 4). They felt that using biofertilizers is better for human health and crop production, as well as being safer and cheaper in comparison to chemical fertilizers (Table 4). Farmers also mentioned improvements to production sustainability, input cost reduction, ecological safety, and organic farming compliance (Table 4). They framed these benefits in terms of bringing back the traditional farming practices that promote the protection of ecology from chemicals (Table 4).

Potential preferences of farmers regarding local or foreign products (biofertilizers) were identified through interview questions. Users and non-users of biofertilizers showed preferences for using both local and foreign made biofertilizers (Tables 3 and 4). One biofertilizer user flagged that choosing a local or foreign product depends on CFU (colony forming unit) count (i.e., microbial concentration) of the biofertilizer (Table 4). For farmers not using biofertilizers, half of the respondent farmers were unwilling to pay more for a product based on its foreign or local origin (Table 3). In the same fashion, farmers using biofertilizers were asked, "would you be willing to pay more for a foreign product than for a local product?" There was a mixed response, with approximately half of the farmers showing willingness (Table 4), although one of them stated that this willingness was conditional on whether the product was found to be better.

It is, however, interesting to note the respondents' willingness to try a new/innovative product. Out of 12 surveyed farmers who do not use biofertilizers, 9 opted to share their willingness on a 10-point scale (with 1 being the most unwilling and 10 being the most willing). The average willingness was 5.89 out of 10 (Table 3), indicating some willingness to use biofertilizers in the future. On the other hand, all 24 biofertilizer-using farmers stated their willingness to try a new/innovative product, with an average of 7.6 out of 10 (Table 4). The fact that these farmers have already adopted biofertilizers may help explain their greater willingness to try new products.

As certification and standards are key to the acceptance and preference of biofertilizers, farmers using chemical fertilizers showed that they trust both local and international organic certification (Table 3). The same was true of farmers using biofertilizers (Table 4), showing that they have equal trust on both kinds of certifications and standards.

\section{DISCUSSION AND INFERENCES}

\section{A. Soil Performance under Chemical Fertilizers}

The perspectives of the surveyed respondents indicate that chemical fertilizers affect the soil, plants, the ecosystem, and human health. When using chemical fertilizers, the soil becomes drought-prone, water-deficit, hard, compact, waterscarce, infertile, polluted and less productive. After the introduction of mineral fertilizers, the intensity of the natural conversion of atmospheric nitrogen to the compounds that can be assimilated by plants is reduced. The mineral salt solutions are harmful to soil microorganisms that form a layer on the fertile soil, and hence the formation of humus slows down [1].

\section{B. Health and Ecological Risks from Chemical Fertilizers}

The respondent groups highlighted that common diseases that can be attributed to usage of chemical fertilizers are skin diseases, kidney problems, respiratory diseases, indigestion, memory loss, lung ailments, mental and physical weakness, menstrual disorders, loss of immunity, loss of work efficiency, eyesight weakness, etc. The use of chemical fertilizers leads to the pollution and poisoning of the water, air, and soil, along with heavy eutrophication of the water bodies. Mineral fertilizers accelerate leaching of calcium from the soil, as well as magnesium, zinc, copper, and manganese [1]. Mineral fertilizers also lead to reducing soil porosity and granular aggregates, and finally, leads to acidification of the soil [1]. Biofertilizers, on the other hand, are safer compared to chemical fertilizers. Biofertilizers do not pollute water and air and keep the environment clean as they trigger oxygenation of the soil.

\section{Soil Performance under Biofertilizers}

Users of biofertilizers found that these products improve soil performance in a number of ways. Soil structure and profile are enhanced along with soil fertility. They are toxinfree, non-poisonous, harmless to soil, environment friendly, and promote disease resistance. Biofertilizers are also seen to support plant and human health, reduce the carbon footprint, and help plants grow better and more safely. Survey results suggest that microbes of biofertilizers solubilize nutrients and micronutrients in the soil and make them available to plant roots. Another identified aspect of microbes acting in the soil is the ability to enhance soil's water retention capacity, enabling the soil to retain moisture. Moisture also remains longer in the soil and sustains the soil during dry spells. Some biofertilizers have additional strength to defy enemy insects and pests, thereby reducing the use of plant protection chemicals. Biofertilizers are also reported to increase plant and soil immunity while improving the quality of produce. Through the formation of microbe colonies on or below the soil surface, the soil particles aggregate together, which helps the soil hold water and air. As a result, plant roots can grow deeper more easily.

\section{Soil-water Regime under Biofertilizers}

Survey results reveal that biofertilizers reduce irrigation needs by at least 2 irrigation for a given crop (e.g., wheat). The moisture accumulates in soil when biofertilizers are applied, as the biofertilizers improve the natural water permeability of the fertile layer of soil. Moisture remains for 
longer in the soil and $40-70 \%$ of this water is kept in the rhizosphere once biofertilizers are applied. The respondents observed that biofertilizers synthesize biologically active substances by dissolving, for example, silicate and other substances including nitrogen, potassium, and phosphorus. This humidifies soil layers and maintains air and water permeability of the soil layer (at least $60 \mathrm{~cm}$ deep) [1]. Some farmers articulated that the bacteria dissolve phosphorus in the soil and increase the salt index level that regulates the $\mathrm{pH}$ of the soil, all of which support plant growth. The bacteria recycle and dissolve intractable phosphorus in soil and make it accessible to the plants. Farmers reported that plant roots can absorb the dissolved nutrients easily from moist soil once the biofertilizers are used. Moisture solubilizes nutrients and enhances uptake by plant roots and hence nutrient intake is facilitated by moisture.

\section{E. Comparative Yield \& Characteristics of Produce}

There is a reported increase in yield and production after using biofertilizers. For example, use of Bacillus amyloliquefaciens (contained in Soil Activator, manufactured by Earth Alive Clean Technologies) in combination with standard fertilization increases the yield of carrots by $32 \%$ versus carrots treated with chemical fertilizers only [3]. Tubers, grains and fruits have better taste, size, quality, production, shelf-life, and color after biofertilizers are used. Noticeably, the size of the harvest depends on the density of the productive stalk and mass of grain from one ear, factors that biofertilizers can improve. The farmers also confirmed that plant products have a more saturated color and better quality once biofertilizers are applied.

\section{F. Comparative Investment and Economic Risks}

Expenditures per unit area of land on chemical pesticides/fertilizers and biofertilizers/biopesticides were compared by the respondent farmers. These expenditures were roughly INR 12,141 per annum per acre on biofertilizers/biopesticides, whereas an average of INR 43,370 per annum per acre was spent for chemical fertilizers and pesticides. While the risk of the losses was quite high (60$70 \%$ ) with chemically grown crops, the risk was only $33 \%$ on average when crops were grown using biologicals. Therefore, risks are considerably lower if biologicals are used [2].

\section{G. Farmers' Preferences for Fertilizers and Biofertilizers}

Nitrogen, phosphorus, and potash are the primary nutrients used in crops. Micronutrients and calcium or magnesium showed the least priority. Common synthetic fertilizers included compound NPK (nitrogen, phosphorus, potassium), calcium nitrate, urea mixture, DAP (diammonium phosphate), MOP (muriate of potash, or potassium chloride), SSP (single super phosphate), and ammonium nitrate. In terms of how biofertilizers are applied, the farmers confirmed that they use chemical fertilizers and biofertilizer(s) simultaneously. In terms of what drives user farmers to spend on biofertilizers, some advantages of using biofertilizers were told to be production sustainability, input cost reduction, cheaper prices, ecologically safe, organic composition, and better health and safety outcomes.

The non-user respondent farmers' average willingness to adopt biofertilizers was measured and found to be 5.89 on a scale of 10 , whereas it is 7.60 out of 10 for users of biofertilizers. Expressed another way, this is nearly $60 \%$ and $75 \%$, respectively, of India's non-user and user farmers. It reflects that users of biofertilizers express greater willingness to adopt biofertilizers, yet the willingness scale of non-users of biofertilizers is not much lower. These farmers indicated preferences for using both local and foreign made biofertilizers. However, they flagged that choosing a local or foreign product depends on the quality of the biofertilizer. Moreover, they also indicated trust in both local and international organic certifications.

\section{CONCLUSION}

Biofertilizers are substances containing beneficial living microorganisms which, when applied to seed, plant surfaces, or soil, colonize the rhizosphere or the interior of the plant and promote growth by increasing the supply or availability of primary nutrients to the host plant. In the soil or rhizosphere, biofertilizers generate plant nutrients like nitrogen and phosphorous through their activities or make them available to the plants. There are 10 different recognized categories of bacterial/fungal biofertilizers being manufactured in India and approved legally. The agronomic advantage of biofertilizers compared to conventional chemical fertilizers is well proved by respondents of the study biologically and in economic terms. Compared to chemical fertilizers, biofertilizers offer ecological and public health safety. Soil biology and the soil-water regime are revived when biofertilizers are applied. In the study, two important economic angles are highlighted by the respondents: a) reduced risks of crop failure if using the biofertilizers; and 2) comparatively lower-cost inputs and less investment are needed to grow crops if biofertilizers are added. Such economic and scientific advantages of using biofertilizers ultimately motivate the farmers to prefer biofertilizers over chemical fertilizers. For instance, Earth Alive Soil Activator is one promising phosphate solubilizing bacteria (PSB) and plant growth-promoting rhizobacteria (PGPR), a composite of three bacteria. The biofertilizer is a broad spectrum and efficient inoculum shown to boost production, soil biology and agroecosystem sustainability [3]. However, a problem lies with the production and supply of biofertilizers in India. Both the production and distribution are inadequate compared to the demand of microbial biofertilizers. With the exception of several ingredients of biofertilizers (e.g., algal base), there is a complete vacuum of imported biofertilizers to overcome the gap between demand and supply. Studies need to be pursued to understand the reasons behind such trade gaps and the slow growth of biofertilizers in the agricultural sector of India.

\section{APPENDIX}

\section{Appendix 1: Questions for Scientists/Academics}

- Scientific features of biologicals being manufactured:

- Composition or ingredients of biologicals;

- Physico-chemical properties or characteristics of biologicals;

- Fertility or Epidemiological functions;

- Efficacy or efficiency of biologicals; 
- Toxicological information;

- Shelf-life of the biological product.

- Characteristics of biologicals:

- How can biofertilizer be distinguished from chemical fertilizer?

- What are the general characteristics of biofertilizers?

- How do biofertilizers function when they are applied onto soil or plants?

- What are ecological functions of biofertilizers?

- Comparative advantage of using biologicals:

- Are biofertilizers economic compared to chemical fertilizers?

- Can you give any calculation of the costs of both?

- How are biofertilizers advantageous to chemical fertilizers?

- What are ecological advantaged of biofertilizers?

- Biosafety and hazardousness related issues: which is better?

- What area advantages related to soil biology?

- How will the use of biofertilizers solve environmental problems?

Appendix 2: Manufacturers, Suppliers, Importers and Traders of Microbial Biofertilizers

\begin{tabular}{|c|c|}
\hline Questions & Responses \\
\hline \multicolumn{2}{|c|}{$\begin{array}{l}\text { What kinds of biologicals in what quantities with what effectiveness } \\
\text { are being used by farmers? }\end{array}$} \\
\hline Categories of & - Rhizobium \\
\hline biofertilizers & - Azotobacter \\
\hline manufactured or & - Acetobacter \\
\hline supplied/traded & - Phosphate Solubilizing Bacteria (PSB) \\
\hline \multirow{18}{*}{$\begin{array}{l}\text { Any efficacy or } \\
\text { efficiency tests/data of } \\
\text { such biofertilizers? }\end{array}$} & - Azospirillum \\
\hline & - Potash Solubilizing Bacteria (KSB) \\
\hline & - Zinc Solubilizing Bacteria (ZSB) \\
\hline & - Mycorrhiza \\
\hline & - Consortia \\
\hline & - Plant growth regulators \\
\hline & - Enzymes \\
\hline & - Plant Tonic \\
\hline & - Sulphur-Iron Solubilizer \\
\hline & - Data not shared \\
\hline & $\begin{array}{l}\text { - Maize, wheat, rice }-20-70 \% \text { increase of yield } \\
\text { by using Azotobacter }\end{array}$ \\
\hline & $\begin{array}{l}\text { Vegetables }-22-30 \% \text { increase of yield by } \\
\text { using Azotobacter }\end{array}$ \\
\hline & - Germination increases by $20-30 \%$ \\
\hline & - $50 \%$ reduction in nitrogen use \\
\hline & - $25-30 \%$ nitrogen saved \\
\hline & $\begin{array}{l}\text { Efficacy data is not required for } \\
\text { biofertilizers. Yet, some data like CFU }\end{array}$ \\
\hline & Count required. \\
\hline & $\begin{array}{l}\text { - Data is collected and analyzed to present to } \\
\text { registration office. }\end{array}$ \\
\hline
\end{tabular}

\section{ACKNOWLEDGEMENT}

The authors acknowledge the funding support provided for this research by Mitacs (grant number IT09485) and Earth Alive Clean Technologies, Inc. The authors also acknowledge the Ethical Approval Certificate (no. CPER-17114-P) issued by the Multi-Faculty Committee on Research Ethics (Comité plurifacultaire d'éthique de la recherche CPER) of Université de Montréal to conduct this research involving different participants.

\section{REFERENCES}

[1] H. Arjjumend, K. Koutouki and O. Donets, "Advantages of Using Biofertilizers in Ukrainian Agroecosystem", Eurasian Journal of Agricultural Research, vol. 4 no. 2, pp.92-123, 2020. Online: https://dergipark.org.tr/en/pub/ejar.

[2] H. Arjjumend and K. Koutouki, "Science of Biopesticides and Critical Analysis of Indian Legal Frameworks Regulating Biocontrol Agents", International Journal of Agriculture, Environment and Biotechnology, vol. 11 no. 3, pp.563-571, 2018. Doi: http://doi.org/10.30954/09741712.06.2018.20.

[3] H. Arjjumend, S. Neufeld, V. Yargeu and M. Warren, "Reviving Soil Biology and Crop Productivity through New Biofertilizer: Agroecological Performance of Pseudomonas monteilli in Tropical Environments", International Journal of Tropical Agriculture, vol. 35

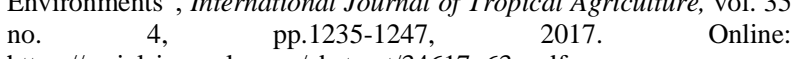
https://serialsjournals.com/abstract/34617_63-.pdf.

[4] C. Franche, K. Lindstrom and C. Elmerich, "Nitrogen fixing bacteria associated with leguminous and non-leguminous plants", Plant and Soil, vol. 321, pp.35-59, 2009.

[5] M. Mazid and T. A. Khan, "Future of Bio-fertilizers in Indian Agriculture: An Overview", International Journal of Agricultural and Food Research, vol. 3 no. 3, pp.10-23, 2014.

[6] S. Neufeld, "Soil biology: third wave ag. Commodities, March 2017. Online: $w w w . s c c f . c h$.

[7] A. D. Noble and S. Ruaysoongnern, "The nature of sustainable agriculture", in Soil Microbiology and Sustainable Crop Production, pp.1-25, R. Dixon and E. Tilston (Eds), Berlin, Heidelberg, Germany: Springer Science and Business Media B.V.

[8] P. Rajendra, S. Singh and S. N. Sharma, "Interrelationship of fertilizers use and other agricultural inputs for higher crop yields", Fertilizers News, vol. 43, pp.35-40, 1998.

[9] K. Rani, V. Sridevi, K.V. Kumar, N. Harsha and C. S. Kumar, "Biotechnological Approach in Biopesticides-An Overview", Elixir Agriculture, vol. 55, pp.12936-12940, 2013.

[10] M. Sharma, "Biofertilzer demand grows with hopes of good monsoon", Times of India, 27 May 2017. Online: https://timesofindia.indiatimes.com/city/indore/biofertilisers-maincopy/articleshow/58864430.cms (Accessed on 09.10.2020).

[11] V. Shiva, "We Are the Soil. The Destructive Impacts of Industrial Agriculture: Biology and life have been replaced with chemistry", Global Research, May 27, 2014. Online: https://www.globalresearch.ca/we-are-the-soil-the-destructiveimpacts-of-industrial-agriculture/5384056.

[12] N. Weyens, D. van der Lelie, S. Taghavi, L. Newman and J. Vangronsveld, "Exploiting plant-microbe partnerships to improve biomass production and remediation", Trends in Biotechnology, vol. 27 no. 10, pp.591-598, 2009.

[13] Z. Wiesman, Desert olive oil cultivation: Advanced BioTechnologies. ISBN-10:0123742579. Cambridge, USA: Academic Press, 2009.

[14] W. Xiang, L. Zhao, X. Xu, Y. Qin and G. Yu, "Mutual Information Flow between Beneficial Microorganisms and the Roots of Host Plants Determined the Bio-Functions of Biofertilizers", American Journal of Plant Sciences, vol. 3, pp.1115-1120, 2012. Doi: http://dx.doi.org/10 .4236/ajps.2012.38134.

[15] V. Yargeau, S. Neufeld and M. Warren, "Organic inputs improving soil microbiology for sustainable agriculture and higher yields. Presented at Scientific Conference "Innovative Research for Organic Agriculture 3.0 ", $19^{\text {th }}$ Organic World Congress, New Delhi, India, November 9-11, 2017, Organized by ISOFAR, NCOF and TIPI.

[16] S. Mosttafiz, M. Rahman and M. Rahman, "Biotechnology: Role of Microbes in Sustainable Agriculture and Environmental Health", The Internet Journal of Microbiology, vol. 10 no. 1, 2012. 